\title{
Phytopathology
}

\section{Host Versus Nonhost Resistance: Distinct Wars with Similar Arsenals}

\author{
Upinder S. Gill, Seonghee Lee, and Kirankumar S. Mysore
}

Plant Biology Division, The Samuel Roberts Noble Foundation, Ardmore, OK 73401.

Accepted for publication 12 January 2015.

\begin{abstract}
Gill, U. S., Lee, S., and Mysore, K. S. 2015. Host versus nonhost resistance: Distinct wars with similar arsenals. Phytopathology 105:580-587.

Plants face several challenges by bacterial, fungal, oomycete, and viral pathogens during their life cycle. In order to defend against these biotic stresses, plants possess a dynamic, innate, natural immune system that efficiently detects potential pathogens and initiates a resistance response in the form of basal resistance and/or resistance $(R)$-gene-mediated defense, which is often associated with a hypersensitive response. Depending upon the nature of plant-pathogen interactions, plants generally have two main defense mechanisms, host resistance and nonhost resistance. Host resistance is generally controlled by single $R$ genes and less durable compared with nonhost resistance. In contrast, nonhost resistance is believed to be a multi-gene trait and more durable. In this review, we describe the mechanisms of host and nonhost resistance against fungal and bacterial plant pathogens. In addition, we also attempt to compare host and nonhost resistance responses to identify similarities and differences, and their practical applications in crop improvement.
\end{abstract}

Additional keywords: gene-for-gene resistance, plant disease resistance, $R$ gene resistance.

Plants are important components of any food chain. During their life cycle, plants are often challenged by numerous abiotic and biotic stresses. Among biotic stresses, diseases caused by fungi, oomycete, bacteria, and viruses have significant economic significance. Fungal and oomycete diseases such as wheat stem rust (caused by Puccinia graminis), Asian soybean rust (caused by Phakopsora pachyrhizi), potato blight (caused by Phytophthora infestans), banana black sigatoka (caused by Mycosphaerella fijiensis), and rice blast (caused by Magnaporthe oryzae) are considered major threats to world food security (Pennisi 2010). In general, plants are resistant to most microorganisms, and there are only a few plant pathogens that have the ability to cause disease (Lipka et al. 2008). In response to pathogen infection, plants have a dynamic immune system comprised of several mechanisms to defend against plant pathogens as previously explained in a four-phased zig-zag model (Jones and Dangl 2006).

Depending upon the nature of the plant-pathogen interactions, plants generally have two types of disease resistance-host resistance and nonhost resistance. Host resistance is mostly cultivar- or accession-specific and less durable (Mysore and Ryu 2004). So far, most of the breeding efforts have focused on host resistance where a single or multiple resistance $(R)$ genes were

Corresponding author: K. S. Mysore; E-mail address: ksmysore@noble.org

http://dx.doi.org/10.1094/PHYTO-11-14-0298-RVW

(C) 2015 The American Phytopathological Society introduced into susceptible cultivars. Unfortunately, resistance imparted by most $R$ genes is less durable because of monocultures, which puts tremendous selection pressure on pathogens to lose or mutate their corresponding effectors to evade detection by the host (Dangl et al. 2013). However, there are some core effectors that contribute toward pathogen virulence (Dangl et al. 2013). Loss/ mutation of such effectors sometimes has negative implications on pathogen virulence and results in improved durability of corresponding host $R$ genes (Vera Cruz et al. 2000). Another form of resistance is nonhost resistance; unlike host resistance, nonhost resistance can act against all races of a particular pathogen and can occur in all cultivars of a host plant species (Heath 2000). Thus, nonhost resistance is more durable and is the common form of plant defense mechanism exhibited by plants toward a vast majority of potential pathogens (Heath 2000; Mysore and Ryu 2004; Niks and Marcel 2009; Senthil-Kumar and Mysore 2013). For a long time, nonhost resistance has been considered to protect crops from many potential pathogens because of its durability (Niks and Marcel 2009). Complete understanding of nonhost resistance mechanisms is imperative to develop cultivars by the transfer of genes involved in nonhost resistance across species (Ayliffe and Lagudah 2004; Zhao et al. 2005). Moreover, nonhost resistance is usually more complicated due to the involvement of multiple pathways.

In this review, we briefly describe the mechanisms of host and nonhost resistance against fungal, oomycete, and bacterial plant pathogens. In addition, we compare host and nonhost resistance 
mechanisms, and highlight the similarities and differences between them. We also compare host and nonhost resistance in terms of their practical application in crop improvement.

\section{MECHANISIMS OF HOST AND NONHOST RESISTANCE}

Host resistance and nonhost resistance are most commonly differentiated based on pathogen adaptation to a particular species (host) and lack of adaptation to other species (nonhost). Both host and nonhost resistances are the outcomes of the plant immune response. Plant innate immunity has been well described in previous reviews (Chisholm et al. 2006; Cohn et al. 2001; Dangl and Jones 2001; Dodds and Rathjen 2010; Jones and Dangl 2006). Among several components of the plant immune response, basal defense is the first line of defense and is initiated during the early phases of pathogen detection. Basal defense in plants is initiated with the perception of evolutionarily conserved microbial- or pathogenassociated molecular patterns (MAMPs or PAMPs) such as flagellin and EF-Tu by plant extracellular pathogen recognition receptors (PRRs) such as leucine-rich repeat kinases (Dangl et al. 2013; Zipfel 2008). Such responses are referred to as PAMP-triggered immunity (PTI). There are also some overlaps between basal defense and nonhost resistance because it is possible that both host and nonhost plants may recognize similar factors to initiate a defense response. Initiation of plant defense responses and the counter attack of pathogen are well explained by the widely accepted zig-zag model proposed by Jones and Dangl (2006). According to this model, there are numerous PRRs in plants to recognize PAMPs and to initiate basal defense responses, but some well-adapted pathogens secrete effectors to evade recognition by plant PRRs and to promote pathogen growth and virulence (Bent and Mackay 2007; Dangl et al. 2013; Zipfel 2008). Suppression of PTI by pathogen effectors leads to effector-triggered susceptibility (ETS). In turn, plants have evolved to recognize these effectors or avirulence (Avr) proteins with the help of R proteins (Nimchuk et al. 2003). Therefore, in response to ETS, host plants trigger R proteins to interact directly or indirectly with pathogen effectors and induce a stronger defense response, referred to as effector-triggered immunity (ETI). There are several examples of direct recognition of pathogen Avr proteins by plant R proteins (Dodds et al. 2006), but in some cases indirect recognition is also possible in which plant decoy proteins interact with Avr proteins and subsequent activation of R proteins (van der Hoorn and Kamoun 2008). This mechanism is also referred to as guard hypothesis (Dangl and Jones 2001; van der Biezen and Jones 1998). Direct and indirect recognition of Avr proteins by $\mathrm{R}$ proteins is followed by a strong defense signaling response that is associated with localized programmed cell death, called hypersensitive response (HR), to limit the pathogen growth.

Both pathogen and host undergo natural selection to diversify effectors and $\mathrm{R}$ proteins to achieve superiority in this molecular arms race (Boller and He 2009). ETI, which is determined by the recognition of a pathogen's effector or Avr protein by corresponding plant $\mathrm{R}$ protein, is also the basis of classical gene-for-gene resistance (Flor 1971). Most R proteins contain a nucleotide-binding site and leucine rich repeats (NBS-LRRs), and are involved, upon recognition of Avr protein, in the development of HR through the generation of reactive oxygen species (ROS). The well-studied host resistance is often considered gene-for-gene resistance and is usually very specific to a particular plant genotype or cultivar and against a particular race of the pathogen (Flor 1971). In contrast, nonhost resistance is not pathogen-race-specific and is a broad spectrum resistance exhibited by the whole plant species against a particular pathogen (Heath 2000). Nonhost resistance is often multi-tiered, with several obstacles depending upon a particular host to stop the colonization by a potential pathogen (ThordalChristensen 2003). These obstacles include, but are not limited to, the presence/absence of signals from plants, such as surface topology features that are required to initiate pathogen growth; preformed barriers such as cell wall, cuticle, phytoanticipins, etc.; and induced defense responses such as lignin accumulation, production of antimicrobials like phytoalexins, HR response, induction of pathogenesis-related (PR) proteins, etc. (SenthilKumar and Mysore 2013; Thordal-Christensen 2003). Depending upon the presence or absence of visual symptoms, nonhost resistance is again divided into type I and type II nonhost resistance (Mysore and Ryu 2004). Type I nonhost resistance does not produce any visual symptoms, whereas type II nonhost resistance is associated with visual necrosis/cell death due to HR (Mysore and Ryu 2004). Type I nonhost resistance typically involves passive or preformed barriers and/or active defense mechanisms that are induced in response to general elicitors of pathogens such as PAMPs (Mysore and Ryu 2004; Thordal-Christensen 2003). Type I nonhost resistance resembles PTI, whereas type II nonhost resistance involves HR and is triggered in response to pathogen elicitor/effector recognition and is similar to ETI (Senthil-Kumar and Mysore 2013). For example, recognition of pathogen effectors by nonhost plant species has been reported previously when AvrA and AvrD from Pseudomonas syringae pv. tomato were recognized by $R$ genes $R p g 2$ and $R p g 4$, respectively, of the nonhost plant soybean (Ashfield et al. 1995; Keen et al. 1991). In addition, AvrRxol from Xanthomonas oryzae pv. oryzae was recognized by the $R$ gene $R x o l$ of the nonhost plant maize (Zhao et al. 2004). Despite the fact that there are some overlaps between host and nonhost resistance, nonhost resistance is more complex and the mechanism of resistance may vary, depending upon the nature of pathogen (virus, bacteria, and fungi) and the plant species.

\section{HOST VERSUS NONHOST RESISTANCE AGAINST FUNGAL AND OOMYCETE PATHOGENS IN PLANTS}

Although nonhost resistance is considered to be a different type than host resistance, there are significant overlaps between them. Fungal pathogens recognize specific plant cues in the form of surface topology or composition of plant waxes (Hoch et al. 1987). Preformed barriers such as surface waxes have been shown to be important for growth and differentiation of nonhost fungal pathogens such as Blumeria graminis f. sp. hordei on cabbage and tobacco, and Phakopsora pachyrhizi on Medicago truncatula (Tsuba et al. 2002; Uppalapati et al. 2012). A mutation in the IRGI (INHIBITOR OF RUST GERM TUBE DIFFERENTIATION 1) gene in $M$. truncatula that causes loss of epicuticular wax accumulation on the abaxial side of the leaf was found to inhibit growth and development of germ tubes of both host and nonhost pathogens (Uppalapati et al. 2012). In contrary, epicuticular waxes were shown to be important for host resistance in cocoa against black pod disease caused by Phytophthora palmivora and Phytophthora megakarya (Nyadanu et al. 2012). In addition, a role of waxes in host resistance was also reported in Lolium spp. against powdery mildew pathogen, Erysiphe graminis (Carver et al. 1990). In both cases, epicuticular wax was directly correlated with resistance, suggesting a positive role of epicuticular waxes in host resistance.

Actin microfilaments are part of the plant cytoskeleton, and the role of actin microfilaments in plant defense is well established (Day et al. 2011). Involvement of ACTIN DEPOLYMERIZATION FACTORS (Adf3 and TaAdf7, a Triticum aestivum homolog of Adf7) in host resistance against rust pathogens has been shown (Fu et al. 2014; Moscou et al. 2011; Wang et al. 2013). Apart from host resistance, nonhost resistance against several nonhost plant-pathogen combinations was compromised when actin polymerization was disrupted with specific inhibitors, indicating the importance of actin microfilaments in nonhost resistance as well (Kobayashi et al. 1997).

Another level of resistance against nonhost pathogens is triggered at the time of pathogen penetration through the plasma membrane. Three PENETRATION genes, PEN1, PEN2, and PEN3, 
have been identified in Arabidopsis and are involved in penetration resistance against the nonhost powdery mildew pathogen Blumeria graminis f. sp. hordei and Asian soybean rust pathogen Phakopsora pachyrhizi (Collins et al. 2003; Lipka et al. 2005; Loehrer et al. 2008; Stein et al. 2006). In Arabidopsis, PEN1 encodes a membraneassociated syntaxin containing a SNARE (soluble $\mathrm{N}$-ethylmaleimide sensitive factor attachment protein receptor) domain which forms a complex with SNAP33 (soluble N-ethylmaleimide-sensitive factor adaptor protein 33) and VAMP721/VAMP722 (vesicle-associated membrane proteins), and is involved in vesicle transport to cell periphery in response to nonhost pathogen $B$. graminis f. sp. hordei (Assaad et al. 2004; Collins et al. 2003; Kwon et al. 2008). Similarly, Required for mlo-specific resistance 1 (Rorl) and Ror 2, an ortholog of $P E N 1$, genes are also involved in penetration resistance in barley against nonhost rust pathogen Phakopsora pachyrhizi (Hoefle et al. 2009). Ror2 is also involved in pre-invasive resistance against host pathogen B. graminis f. sp. hordei (Collins et al. 2003). In Arabidopsis, PEN2, ARABIDOPSIS G PROTEIN BETA SUBUNIT 1 (AGB1), POWDERY MILDEW RESISTANT 5 (PMR5), and MILDEW RESISTANCE LOCUS O (MLO2) genes are involved in both pre- and postinvasive nonhost resistance against $B$. graminis f. sp. hordei (Nakao et al. 2011). PMR5 restricts fungal hyphae elongation whereas $A G B 1$ and $M L O 2$ restrict both hyphae elongation and branching of nonhost pathogen $B$. graminis f. sp. hordei (Nakao et al. 2011). The Mlo family gene was first identified in barley, but unlike Arabidopsis $M L O 2$, mutation in the Mlo locus of barley conferred durable resistance against biotrophic host pathogen $B$. graminis f. sp. hordei and hyper-susceptibility against hemi-biotrophic nonhost pathogen Magnaporthe oryzae, indicating the involvement of yet another gene in both host and nonhost resistance, even though the outcome was antagonistic (Buschges et al. 1997; Jarosch et al. 1999). However, the Mlo gene product is considered to act as a negative regulator of cell death due to the association of a mutation in Mlo with resistance against biotrophic fungal pathogens and susceptibility against necrotrophic fungal pathogens (Király et al. 2002). Barley mlo alleles cause enhanced susceptibility against host pathogens Bipolaris sorokiniana, a necrotroph, and Ramularia collo-cygni, which lives in host as an endophyte but later changes to necrotrophic mode (Kumar et al. 2001; McGrann et al. 2014).

Fungal pathogens that successfully overcome penetration or preinvasion resistance produce infection hyphae and/or haustoria to absorb nutrients from plant cells. At this point, pathogens encounter postinvasion resistance from plants. Plant genes such as ENHANCED DISEASE SUSCEPTIBILITY 1 (EDS1), PHYTOALEXIN DEFICIENT 4 (PAD4), and SENESCENCE ASSOCIATED GENE 101 (SAG101), which are also involved in basal defense during host-pathogen interactions, are also implicated in postinvasion defense (Lipka et al. 2005; Stein et al. 2006). Individual mutations in these genes have an effect on postinvasion defense in Arabidopsis against nonhost pathogen B. graminis f. sp. hordei. In addition, a triple mutant of pen2/pad4/eds 1 completely broke down the nonhost resistance barrier against $B$. graminis f. sp. hordei and pea powdery mildew pathogen Erysiphe pisi (Lipka et al. 2005). EDS1 was initially identified in Arabidopsis as a component of basal defense against host pathogen Hyaloperonospora parasitica (Parker et al. 1996). EDS1 and PAD4 are also required for several Arabidopsis $R$ genes belonging to TIR-NB-LRR class-mediated resistance (Wiermer et al. 2005). Apart from a few plant genes that are commonly required for host and nonhost resistance, some effectors are also commonly recognized by host and nonhost plant species. For example, Avr3a of Phytophthora infestans and Avrlb-1, a homolog of Avr3a in Phytophthora sojae, are recognized by their corresponding host $R$ genes, $R 3 a$ of potato and $R p s 1 b$ of soybean, respectively (Armstrong et al. 2005; Shan et al. 2004). In addition, PcAvr3al of Phytophthora capsici, which is also a homolog of Avr3a of Phytophthora infestans, is recognized by a dominant $R$ gene of nonhost Nicotiana species, indicating parallel mechanisms among host and nonhost resistance (Vega-Arreguín et al. 2014).

Additionally, there are several examples where potential $R$ genes were identified in nonhost plant species, and after transferring to host plant species, those $R$ genes have successfully conferred resistance against host pathogens (Sumit 2013; Zhao et al. 2005). Examples of successful transgenic deployment of $R$ genes between plant species have been reviewed previously (Wulff et al. 2011). These studies indicate a conserved mechanism involved downstream of recognition among various plant species, irrespective of their classification as host or nonhost (Stam et al. 2014).

At the cellular level, both nonhost and host resistance are associated with similar cellular responses such as cytoplasmic aggregation involving relocation of organelles, production of ROS, and HR (Hückelhoven et al. 2001; Hückelhoven and Kogel 2003; Takemoto et al. 2003; Vleeshouwers et al. 2000). However, apart from overlaps or similarities in host and nonhost resistance mechanisms, there is evidence that also suggests distinct or independent mechanisms. Distinct cellular processes and timing of HR have also been reported among host and nonhost interactions against penetration of rust and powdery mildew fungi in cowpea and French beans (Christopher-Kozjan and Heath 2003). In nonhost interactions, the cell death process was rapid (less than one hour) and the plant cell nucleus was seen associated with fungal haustorium. During host resistance in contrast to nonhost resistance, the cell death response took longer (two or more hours) and no consistent association of plant cell nucleus with the intracellular fungi was found (Christopher-Kozjan and Heath 2003). Nonetheless, no differences were observed in cellular signaling during HR, such as influx of calcium and protein kinase activity between host and nonhost resistance (Christopher-Kozjan and Heath 2003). However, there are also few examples where plant nucleus has been shown to be associated with the pathogen structures, such as haustoria, during host resistance (Griffis et al. 2014). For example, during host resistance of a potato cultivar (Solanum tuberosum L. cv. Datura) against oomycete pathogen Phytophthora infestans (race 4) the plant cell nucleus conglomerate around the intracellular oomycete haustorium which is followed by cell death response (Freytag et al. 1994). Based on our current understanding, host and nonhost mechanisms against fungal and oomycete pathogens have some similarities and overlaps by the involvement of common genes in both types of resistance but are yet distinct in recognition and initiation of defense response.

\section{HOST VERSUS NONHOST RESISTANCE AGAINST BACTERIAL PATHOGENS IN PLANTS}

Similar to the way plants have evolved to combat infections by fungal and oomycete pathogens, plants have also evolved defense mechanisms to prevent attacks from bacterial pathogens. Most bacterial pathogens get access to the plant milieu through natural openings (hydathodes and stomata) and wounds (Hirano and Upper, 1983). The most studied plant pathogenic bacteria belong to the genus Pseudomonas (type III secretion), Xanthomonas (type III secretion), Erwinia (type II secretion), Ralstonia (type III secretion), and Agrobacterium (type IV secretion). Species within these genera of bacterial pathogens use different types of secretion systems to secrete effector proteins into a host cell for the suppression of plant defense systems. Many gram-negative plant bacterial pathogens employ a type III secretion system (T3SS) to colonize host plants by suppressing plant defense (Buttner and $\mathrm{He}$ 2009). For example, AvrPto from Pseudomonas syringae pv. tomato blocks callose deposition in tomato plants (Hauck et al. 2003) and suppresses HR induced in nonhost plants (Kang et al. 2004). In Arabidopsis, AvrRpm1 (from Pseudomonas syringae pv. maculicola) and AvrRpt2 (from Pseudomonas syringae pv. tomato) effectors 
inhibit PAMP-mediated defense signaling pathways (Kim et al. 2009). Plants, on the other hand, have evolved to express $R$ proteins that can detect the presence of T3SS effectors inside the plant cell and initiate defense responses such as HR, ROS production, and expression of $P R$ genes. As described above, this phenomenon is also referred to as ETI. In contrast to R proteinmediated host resistance, early recognition of bacterial PAMPs is also important for initiating the downstream signaling pathway for nonhost resistance. PRRs recognize bacterial PAMPs, induce defense signaling and defend against nonadapted bacterial pathogens. In Arabidopsis, flagellin (a PAMP)-induced defense plays an important role in nonhost resistance against bacterial pathogens ( $\mathrm{Li}$ et al. 2005). The flg22 peptide of flagellin from Pseudomonas bacteria is perceived by FLS2, a receptor-like kinase that activates downstream events. It has been reported that ROS and defense phytohormones, such as salicylic acid (SA), jasmonic acid (JA), and abscisic acid (ABA), play a role in the defense signaling pathway for nonhost resistance (Li et al. 2012; Mishina and Zeier 2007; van Wees and Glazebrook 2003). Since SA, JA, and ABA are the major hormones for plant defense and development, genes involved in their signaling pathway are not only involved in nonhost resistance but also closely associated with plant growth and development.

Several plant genes and proteins have been identified that play a role in both host and nonhost resistance. For example, in Nicotiana benthamiana, the suppressor of the G2 allele of S-phase kinaseassociated protein 1 (SGT1) has been known for the production of ROS and HR cell death against nonhost bacterial pathogens (Shibata et al. 2011; Wang et al. 2010). Also, SGT1 together with Rar1 (Required for Mla12 Resistance 1) is required for resistance responses mediated by NBS-LRR and other R proteins (Azevedo et al. 2002; Peart et al. 2002). GLYCOLATE OXIDASE (GOX) and NONHOST 1 (NHOI) genes have also been demonstrated to be required for both host and nonhost resistance in Arabidopsis (Lu et al. 2001; Rojas et al. 2012). Another important gene for the SA signaling pathway, EDS1, also contributes to host, nonhost, and basal resistance against bacterial pathogens (Aarts et al. 1998; Glazebrook 2001; Moreau et al. 2012). Apart from plant genes, several pathogen genes also determine host/nonhost status of a plant. In Pseudomonas, several survival in Arabidopsis extracts ( $\operatorname{sax}$ ) genes in host bacterial strains are implicated in overcoming Arabidopsis defense. Depending upon the presence or absence of sax genes, Arabidopsis host or nonhost status against certain bacterial pathogens is decided (Fan et al. 2011).

\section{EVOLUTIONARY PERSPECTIVE OF HOST AND NONHOST RESISTANCE}

The concept of host and nonhost resistance is derived from the fact that not all pathogens can infect all plant species. Host and nonhost interactions between plants and pathogens are dynamic and greatly influenced by evolution. At the molecular level, depending upon the genetic distance from the host species, host resistance is predominantly regulated by ETI, whereas nonhost resistance is regulated by PTI and/or ETI (Schulze-Lefert and Panstruga 2011; Senthil-Kumar and Mysore 2013) (Fig. 1). Within host species, the variation of resistance among cultivars and accessions is mainly defined by a large repertoire of $R$ genes that continuously evolve due to gene duplication/deletion, recombination, mutations, and selection pressure for resistance against pathogens (Ellis et al. 2000). On the other hand, pathogens also evolve their effector proteins to maintain virulence on host species. Co-evolution of host and pathogen is also the basis of the zig-zag model that has been developed for plant immunity against pathogens (Jones and Dangl 2006). In some instances, the host plant evolves and acquires a nonhost status by one-sided evolution of the plant while the pathogen is specialized to a particular host and does not counter evolve (Antonovics et al. 2013). Generally, durability of nonhost resistance increases against a specialized pathogen when the nonhost species is evolutionarily divergent from the source host species (Fig. 1). On the contrary, highly evolving pathogens have the potential to overcome the defense exhibited by nonhost species evolutionarily divergent from their source host (Fig. 1). In general, an increase in genetic distance of nonhost from adapted host increases the durability of nonhost resistance because of the presence of several mechanisms to block the pathogen infection (Antonovics et al. 2013). Additionally, pathogens which keep evolving generally have a large host range. Several factors which influence genetic structure and evolutionary trajectory of a pathogen population include the host range, mode of reproduction, transmission and dispersal, life-cycle complexity and epidemiology, and host longevity (Barrett et al. 2008). A good example of a pathogen with a large host range, long-distance transmission, sexual and asexual modes of reproduction, and a complex life cycle including an alternate host is Puccinia spp. The Puccinia spp. cause rust diseases in monocots and cause economically significant damage on several crop plants in the United States (Roelfs 1978). The host range of Puccinia graminis alone is very large and covers 365 species in 54 genera (Anikster 1984). Another example is Puccinia

\section{FIGURE 1}

Evolution of host and nonhost resistance. A, Host resistance is primarily controlled by R-AVR recognition. A micro-evolution creates diversity within host species for resistance/susceptibility and also within pathogen to develop new races with diverse suite of effectors. Red, yellow, and green indicate host var-

iations for susceptibility, partial resistance/susceptibility, and resistance, respectively. B, Outcomes of nonhost interactions vary with genetic distance from host species and the pathogen's ability to evolve. A rapidly evolving pathogen due to co-speciation, host shift, and host jump has better capability to adapt to new nonhost species by breaking the nonhost barriers. Durability of nonhost resistance with respect to genetic distance is depicted as a gradient from red to green, where red is less durable and green is more durable. The contribution of

PAMP-triggered immunity and effector-triggered immunity also increases and decreases, respectively, with the increase in genetic distance from host to nonhost (based on information from Schulze-Lefert and Panstruga 2011).

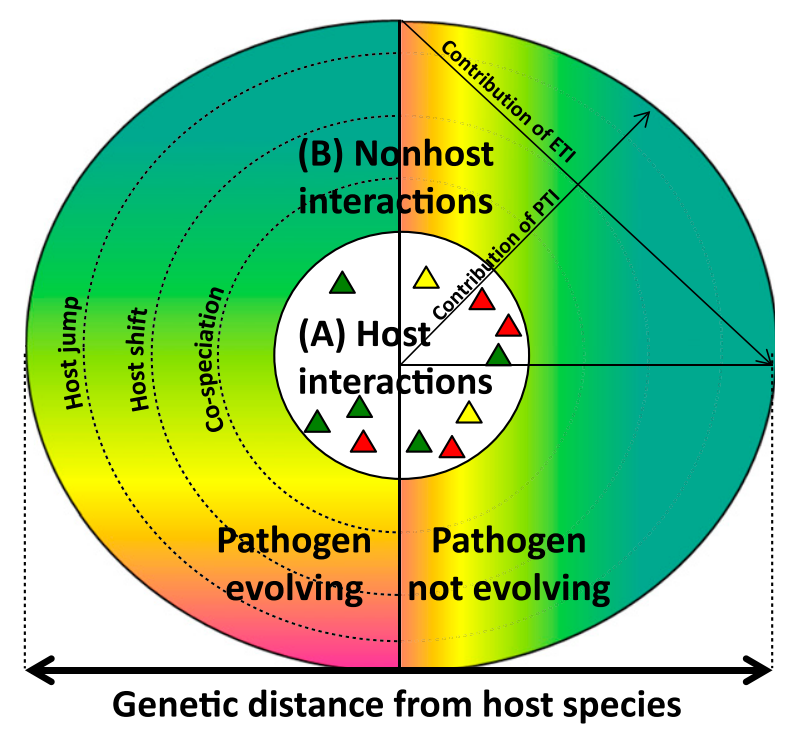

Vol. 105, No. 5, 2015 
coronata var. hordei, also has a broad host range and infects Hordeum, Bromus, Agropyron, Aegilops, Phalaris, and Secale genera (Jin and Steffenson 1999). It can be presumed that such pathogens have a large repertoire of effectors compared to a specialized pathogen (Niks and Marcel 2009). Recently, a new race (Ug99) of Puccinia graminis f. sp. tritici emerged in Uganda in 1998 which is virulent on most wheat cultivars grown all over the world (Pretorius et al. 2000; Singh et al. 2011). Sexual reproduction and long distance dispersal of windborne spores are the major contributing factors for emergence of new races and rust epidemics. Intercontinental long-distance dispersal of Puccinia graminis f. sp. tritici has been reported previously (Watson 1981). Puccinia graminis f. sp. tritici overwinters and completes its sexual cycle on the alternate host barberry (Berberis vulgaris), and the presence of barberries increases genetic diversity and infectivity of rust (Burdon and Roelfs 1985). Therefore, a barberry eradication program was conducted from 1918 to 1980 in the United States to reduce wheat stem rust epidemics (Roelfs 1982).

Apart from co-evolution, which largely determines host-pathogen interactions, co-speciation, host-shift speciation, and host jump play a role in the adaptation of pathogens to new plant species (Fig. 1) (Schulze-Lefert and Panstruga 2011; de Vienne et al. 2013). Co-speciation happens when both host and pathogen undergo speciation simultaneously to maintain their interactions. The presence of co-speciation has been experimentally proven by comparing phylogenetic trees of rodents and their ectoparasites, which showed a high degree of concordance (Hafner and Nadler 1988). Host-shift happens when pathogens usually shift from their natural host to related nonhost species. For example, Blumeria graminis that causes powdery mildew disease on barley underwent host-shift from barley to the related nonhost species, wheat (Inuma et al. 2007). Similarly, rice blast pathogen Magnaporthe oryzae also shifted host to cause wheat blast in the mid-1980s (Couch et al. 2005). On the other hand, host jump involves adaption of the pathogen to a distantly related plant species from their source host or sometimes even across kingdom (Raffaele et al. 2010; van Baarlen et al. 2007). For example, many plant bacterial and fungal pathogens such as Pseudomonas aeruginosa, Agrobacterium radiobacter, Alternaria spp., and Fusarium spp. have a wide plant host range but are also capable of infecting mammalian hosts indicating a cross kingdom jump in the past (van Baarlen et al. 2007). A very good example of host jump is related to Phytophthora infestans that was responsible for the famous 19th century Irish potato famine. Phytophthora infestans that infect several Solanum species evolved through host jump from Phytophthora mirabilis that infect the four o'clock plant (Mirabilis jalapa) (Grünwald and Flier 2005; Raffaele et al. 2010). Recent findings suggest that the host specialization followed by host jump is dependent on reciprocal amino acid changes in effector proteins such as a single amino acid change in one of the effector protein that binds and inhibits a plant's protease defense (Dong et al. 2014; Raffaele et al. 2010). Horizontal gene transfer of pathogenicity genes between pathogen species beyond reproductive barriers also helps bacterial and fungal pathogens to shift their hosts and infect nonhosts (de la Cruz and Davies 2000; Rosewich and Kistler 2000). Interspecific horizontal gene transfer has been reported for the ToxA gene that was transferred from Phaeosphaeria nodorum to Pyrenophora tritici-repentis, which causes tan spot disease of wheat (Friesen et al. 2006).

Based on the current understanding, plant pathogen interactions are highly influenced by evolutionary forces that act on both plants and pathogens. Host and nonhost status is decided by both plant and pathogen, which is again affected by speciation, biology of plant, and pathogen, including mode of reproduction, geographical proximity, epidemiology, and host range of the pathogen.

\section{HOST VERSUS NONHOST RESISTANCE: PRACTICAL APPLICATION FOR CROP IMPROVEMENT}

Compared with host resistance, nonhost resistance is considered more durable; but at the same time, nonhost resistance is more complicated and difficult to apply in crop breeding. Availability of both susceptible and resistant individuals in host populations against a particular pathogen makes it easier to identify underlying genetic factors responsible for resistance by employing genetic and quantitative trait loci mapping. Contrarily, a nonhost plant population generally lacks susceptible individuals, especially if the nonhost is distantly related to the susceptible host. Under these circumstances, inheritance of nonhost resistance can be achieved by employing three different strategies: crossing host $\times$ nonhost where cross species hybridization is possible; crossing nonhost $\times$ nonhost if there are variations in resistance; and crossing rare susceptible and common resistant individuals in marginal host species (Niks and Marcel 2009). Marginal host species are those which are mostly nonhost to a pathogen species, but rarely individuals with lower susceptibility than host species still exist (Niks and Marcel 2009). Lack of natural variation for resistance in host and nonhost species can be overcome by generating variations using mutagenesis and gene silencing. Several genes involved in nonhost resistance of $M$. truncatula against Phakopsora pachyrhizi were identified by screening a large Tntl insertion mutagenized population of $M$. truncatula (Tadege et al. 2008; Uppalapati et al. 2012). In addition, $P E N$ genes were identified and characterized in nonhost Arabidopsis by screening a mutant population upon infection with Blumeria graminis f. sp. hordei (Collins et al. 2003; Lipka et al. 2005; Stein et al. 2006). In another approach, virus-induced gene silencing (VIGS)-based forward genetics screening was utilized to identify the role of genes such as SQUALENE SYNTHASE (SQS), GOX, ORNITHINE DELTAAMINOTRANSFERASE (SOAT), and PROLINE DEHYDROGENASE $(P r o D H)$ in nonhost resistance of $N$. benthamiana against several bacterial pathogens (Rojas et al. 2012; Senthil-Kumar and Mysore 2012; Wang et al. 2012).

The next step after identification of genes involved in nonhost resistance is to successfully transfer them to susceptible host species. Genes involved in nonhost resistance are often difficult to transfer compared with host resistance genes, since they need either wide hybridization or transgenic approaches. Wide hybridization has been successfully employed in the past to transfer sources of resistance against multiple diseases in wheat by transferring individual rye chromosomes to wheat (Riley and Macer 1966). More recently, a barley leaf rust resistance gene, $R p h 22$, was successfully transferred from nonhost species Hordeum bulbosum to Hordeum vulgare (cultivated barley) (Johnston et al. 2013). Similarly, a transgenic approach has also been implemented successfully in the past in which a nonhost resistance gene, Rxol, from maize was transferred to rice and imparted resistance against the bacterial streak pathogen Xanthomonas oryzae pv. oryzicola (Zhao et al. 2005). Recently, another Arabidopsis gene involved in nonhost resistance, PHYTOPHTHORA SOJAE SUSCEPTIBLE 1 (PSS1), was identified in the Arabidopsis pen1-1 mutant background which is required for both pre- and post-penetration nonhost resistance against the hemibiotrophic oomycete fungal pathogen Phytophthora sojae and necrotrophic fungal pathogen Fusarium virguliforme (Sumit et al. 2012). PSS1 encodes a glycine-rich protein (GRP), and expression of AtGRPl in soybean cultivar Williams-82 led to enhanced resistance against Phytophthora sojae and $F$. virguliforme (Sumit 2013).

\section{CONCLUDING REMARKS}

Host resistance has been studied extensively, but nonhost resistance is only beginning to be understood. Host resistance is mainly controlled by gene-for-gene resistance, whereas nonhost 
resistance is usually more complicated due to the involvement of multiple pathways. Due to the durability of nonhost resistance over host resistance, nonhost resistance holds great promise for agriculture. Based on the available information on host and nonhost resistance, we compared these two forms of resistance. Despite their classification into two classes, host and nonhost resistance share more similarities than differences in their mechanisms and resistance process. Due to similarities in downstream mechanisms, genes involved in nonhost resistance have been successfully transferred from nonhost to host species (Johnston et al. 2013; Sumit 2013; Zhao et al. 2005). But identification and utilization of sources of nonhost resistance in crop improvement are still challenging. We speculate that with the aid of the latest molecular biology and genomics tools, such as improved transformation methods, advanced tissue culture techniques, mutagenesis, genome editing, VIGS, and genome sequencing, more novel sources of nonhost resistance will be identified and effectively utilized in future plant breeding.

\section{LITERATURE CITED}

Aarts, N., Metz, M., Holub, E., Staskawicz, B. J., Daniels, M. J., and Parker, J. E. 1998. Different requirements for EDS1 and NDRI by disease resistance genes define at least two $R$ gene-mediated signaling pathways in Arabidopsis. Proc. Natl. Acad. Sci. USA 95:10306-10311.

Anikster, Y. 1984. The formae speciales. Pages 115-130 in: The Cereal Rusts. Vol. I. W. R. Bushnell and A. P. Roelfs, eds. Academic Press, Orlando.

Antonovics, J., Boots, M., Ebert, D., Koskella, B., Poss, M., and Sadd, B. M. 2013. The origin of specificity by means of natural selection: Evolved and nonhost resistance in host-pathogen interactions. Evolution 67:1-9.

Armstrong, M. R., Whisson, S. C., Pritchard, L., Bos, J. I., Venter, E., Avrova, A. O., Rehmany, A. P., Bohme, U., Brooks, K., Cherevach, I., Hamlin, N., White, B., Fraser, A., Lord, A., Quail, M. A., Churcher, C., Hall, N., Berriman, M., Huang, S., Kamoun, S., Beynon, J. L., and Birch, P. R. 2005. An ancestral oomycete locus contains late blight avirulence gene Avr3a, encoding a protein that is recognized in the host cytoplasm. Proc. Natl. Acad. Sci. USA 102:7766-7771.

Ashfield, T., Keen, N. T., Buzzell, R. I., and Innes, R. W. 1995. Soybean resistance genes specific for different Pseudomonas syringae avirulence genes are allelic, or closely linked, at the RPG1 locus. Genetics 141: 1597-1604.

Assaad, F. F., Qiu, J. L., Youngs, H., Ehrhardt, D., Zimmerli, L., Kalde, M., Wanner, G., Peck, S. C., Edwards, H., Ramonell, K., Somerville, C. R., and Thordal-Christensen, H. 2004. The PEN1 syntaxin defines a novel cellular compartment upon fungal attack and is required for the timely assembly of papillae. Mol. Biol. Cell 15:5118-5129.

Ayliffe, M. A., and Lagudah, E. S. 2004. Molecular genetics of disease resistance in cereals. Ann. Bot. (Lond.) 94:765-773.

Azevedo, C., Sadanandom, A., Kitagawa, K., Freialdenhoven, A., Shirasu, K., and Schulze-Lefert, P. 2002. The RAR1 interactor SGT1, an essential component of $R$ gene-triggered disease resistance. Science 295:2073-2076.

Barrett, L. G., Thrall, P. H., Burdon, J. J., Nicotra, A. B., and Linde, C. C. 2008. Population structure and diversity in sexual and asexual populations of the pathogenic fungus Melampsora lini. Mol. Ecol. 17:3401-3415.

Bent, A. F., and Mackey, D. 2007. Elicitors, effectors, and $R$ genes: The new paradigm and a lifetime supply of questions. Annu. Rev. Phytopathol. 45: 399-436.

Boller, T., and He, S. Y. 2009. Innate immunity in plants: An arms race between pattern recognition receptors in plants and effectors in microbial pathogens. Science 324:742-744.

Burdon, J. J., and Roelfs, A. P. 1985. The Effect of Sexual and Asexual Reproduction on the Isozyme Structure of Populations of Puccinia graminis. American Phytopathological Society, St. Paul, MN.

Buschges, R., Hollricher, K., Panstruga, R., Simons, G., Wolter, M., Frijters, A., van Daelen, R., van der Lee, T., Diergaarde, P., Groenendijk, J., Topsch, S., Vos, P., Salamini, F., and Schulze-Lefert, P. 1997. The barley Mlo gene: A novel control element of plant pathogen resistance. Cell 88:695-705.

Buttner, D., and He, S. Y. 2009. Type III protein secretion in plant pathogenic bacteria. Plant Physiol. 150:1656-1664

Carver, T. W. L., Thomas, B. J., Ingerson-Morris, S. M., and Roderick, H. W. 1990. The role of abaxial leaf surface waxes of Lolium spp. in resistance to Erysiphe graminis. Plant Pathol. 39:573-583.

Chisholm, S. T., Coaker, G., Day, B., and Staskawicz, B. J. 2006. Host-microbe interactions: Shaping the evolution of the plant immune response. Cell 124: 803-814.
Christopher-Kozjan, R., and Heath, M. C. 2003. Cytological and pharmacological evidence that biotrophic fungi trigger different cell death execution processes in host and nonhost cells during the hypersensitive response. Physiol. Mol. Plant Pathol. 62:265-275.

Cohn, J., Sessa, G., and Martin, G. B. 2001. Innate immunity in plants. Curr. Opin. Immunol. 13:55-62.

Collins, N. C., Thordal-Christensen, H., Lipka, V., Bau, S., Kombrink, E., Qiu, J. L., Huckelhoven, R., Stein, M., Freialdenhoven, A., Somerville, S. C., and Schulze-Lefert, P. 2003. SNARE-protein-mediated disease resistance at the plant cell wall. Nature 425:973-977.

Couch, B. C., Fudal, I., Lebrun, M. H., Tharreau, D., Valent, B., van Kim, P., Notteghem, J. L., and Kohn, L. M. 2005. Origins of host-specific populations of the blast pathogen Magnaporthe oryzae in crop domestication with subsequent expansion of pandemic clones on rice and weeds of rice. Genetics 170:613-630.

Dangl, J. L., Horvath, D. M., and Staskawicz, B. J. 2013. Pivoting the plant immune system from dissection to deployment. Science 341:746-751.

Dang1, J. L., and Jones, J. D. G. 2001. Plant pathogens and integrated defense responses to infection. Nature 411:826-833.

Day, B., Henty, J. L., Porter, K. J., and Staiger, C. J. 2011. The pathogen-actin connection: A platform for defense signaling in plants. Annu. Rev. Phytopathol. 49:483-506.

de la Cruz, F., and Davies, J. 2000. Horizontal gene transfer and the origin of species: Lessons from bacteria. Trends Microbiol. 8:128-133.

de Vienne, D. M., Refregier, G., Lopez-Villavicencio, M., Tellier, A., Hood, M. E., and Giraud, T. 2013. Cospeciation vs. host-shift speciation: Methods for testing, evidence from natural associations and relation to coevolution. New Phytol. 198:347-385.

Dodds, P. N., Lawrence, G. J., Catanzariti, A. M., Teh, T., Wang, C. I. A., Ayliffe, M. A., Kobe, B., and Ellis, J. G. 2006. Direct protein interaction underlies gene-for-gene specificity and coevolution of the flax resistance genes and flax rust avirulence genes. Proc. Natl. Acad. Sci. USA 103: 8888-8893.

Dodds, P. N., and Rathjen, J. P. 2010. Plant immunity: Towards an integrated view of plant-pathogen interactions. Nat. Rev. Genet. 11:539-548.

Dong, S., Stam, R., Cano, L. M., Song, J., Sklenar, J., Yoshida, K., Bozkurt, T. O., Oliva, R., Liu, Z., Tian, M., Win, J., Banfield, M. J., Jones, A. M., van der Hoorn, R. A., and Kamoun, S. 2014. Effector specialization in a lineage of the Irish potato famine pathogen. Science 343:552-555.

Ellis, J., Dodds, P., and Pryor, T. 2000. Structure, function and evolution of plant disease resistance genes. Curr. Opin. Plant Biol. 3:278-284.

Fan, J., Crooks, C., Creissen, G., Hill, L., Fairhurst, S., Doerner, P., and Lamb, C. 2011. Pseudomonas sax genes overcome aliphatic isothiocyanatemediated non-host resistance in Arabidopsis. Science 331:1185-1188.

Flor, H. H. 1971. Current status of the gene-for-gene concept. Annu. Rev. Phytopathol. 9:275-296.

Freytag, S., Arabatzis, N., Hahlbrock, K., and Schmelzer, E. 1994. Reversible cytoplasmic rearrangements precede wall apposition, hypersensitive cell death and defense-related gene activation in potato/Phytophthora infestans interactions. Planta 194:123-135.

Friesen, T. L., Stukenbrock, E. H., Liu, Z., Meinhardt, S., Ling, H., Faris, J. D., Rasmussen, J. B., Solomon, P. S., McDonald, B. A., and Oliver, R. P. 2006. Emergence of a new disease as a result of interspecific virulence gene transfer. Nat. Genet. 38:953-956.

Fu, Y., Duan, X., Tang, C., Li, X., Voegele, R. T., Wang, X., Wei, G., and Kang, Z. 2014. TaADF7, an actin-depolymerizing factor, contributes to wheat resistance against Puccinia striiformis f. sp. tritici. Plant J. 78:16-30.

Glazebrook, J. 2001. Genes controlling expression of defense responses in Arabidopsis-2001 status. Curr. Opin. Plant Biol. 4:301-308.

Griffis, A. H., Groves, N. R., Zhou, X., and Meier, I. 2014. Nuclei in motion: Movement and positioning of plant nuclei in development, signaling, symbiosis, and disease. Front. Plant Sci. 5:129.

Grünwald, N. J., and Flier, W. G. 2005. The biology of Phytophthora infestans at its center of origin. Annu. Rev. Phytopathol. 43:171-190.

Hafner, M. S., and Nadler, S. A. 1988. Phylogenetic trees support the coevolution of parasites and their hosts. Nature 332:258-259.

Hauck, P., Thilmony, R., and He, S. Y. 2003. A Pseudomonas syringae type III effector suppresses cell wall-based extracellular defense in susceptible Arabidopsis plants. Proc. Natl. Acad. Sci. USA 100:8577-8582.

Heath, M. C. 2000. Nonhost resistance and nonspecific plant defenses. Curr. Opin. Plant Biol. 3:315-319.

Hirano, S. S., and Upper, C. D. 1983. Ecology and epidemiology of foliar bacterial plant pathogens. Annu. Rev. Phytopathol. 21:243-270.

Hoch, H. C., Staples, R. C., Whitehead, B., Comeau, J., and Wolf, E. D. 1987. Signaling for growth orientation and cell differentiation by surface topography in uromyces. Science 235:1659-1662.

Hoefle, C., Loehrer, M., Schaffrath, U., Frank, M., Schultheiss, H., and Huckelhoven, R. 2009. Transgenic suppression of cell death limits 
penetration success of the soybean rust fungus Phakopsora pachyrhizi into epidermal cells of barley. Phytopathology 99:220-226.

Hückelhoven, R., Dechert, C., and Kogel, K. H. 2001. Non-host resistance of barley is associated with a hydrogen peroxide burst at sites of attempted penetration by wheat powdery mildew fungus. Mol. Plant Pathol. 2: 199-205.

Hückelhoven, R., and Kogel, K. H. 2003. Reactive oxygen intermediates in plant-microbe interactions: Who is who in powdery mildew resistance? Planta 216:891-902.

Inuma, T., Khodaparast, S. A., and Takamatsu, S. 2007. Multilocus phylogenetic analyses within Blumeria graminis, a powdery mildew fungus of cereals. Mol. Phylogenet. Evol. 44:741-751.

Jarosch, B., Kogel, K. H., and Schaffrath, U. 1999. The ambivalence of the barley Mlo locus: Mutations conferring resistance against powdery mildew (Blumeria graminis f. sp. hordei) enhance susceptibility to the rice blast fungus Magnaporthe grisea. Mol. Plant-Microbe Interact. 12:508-514.

Jin, Y., and Steffenson, B. J. 1999. Puccinia coronata var. hordei var. nov.: Morphology and pathogenicity. Mycologia 91:877-884.

Johnston, P. A., Niks, R. E., Meiyalaghan, V., Blanchet, E., and Pickering, R. 2013. Rph22: Mapping of a novel leaf rust resistance gene introgressed from the non-host Hordeum bulbosum L. into cultivated barley (Hordeum vulgare L.). Theor. Appl. Genet. 126:1613-1625.

Jones, J. D., and Dangl, J. L. 2006. The plant immune system. Nature 444: 323-329.

Kang, L., Tang, X., and Mysore, K. S. 2004. Pseudomonas type III effector AvrPto suppresses the programmed cell death induced by two nonhost pathogens in Nicotiana benthamiana and tomato. Mol. Plant-Microbe Interact. 17:1328-1336.

Keen, N., Kobayashi, D., Tamaki, S., Shen, H., Stayton, M., Lawrence, D., Sharma, A., Midland, S., Smith, M., and Sims, J. 1991. Avirulence gene D from Pseudomonas Syringae pv. tomato and its interaction with resistance gene Rpg4 in soybean. Pages 37-44 in: Advances in Molecular Genetics of Plant-Microbe Interactions. Vol. 1. H. Hennecke and D. Verma, eds. Springer, The Netherlands.

Kim, M. G., Geng, X., Lee, S. Y., and Mackey, D. 2009. The Pseudomonas syringae type III effector AvrRpm1 induces significant defenses by activating the Arabidopsis nucleotide-binding leucine-rich repeat protein RPS2. Plant J. 57:645-653.

Király, L., Kumar, J., Hückelhoven, R., and Kogel, K. H. 2002. mlo5, a resistance gene effective against a biotrophic pathogen (Blumeria graminis $\mathrm{f}$. sp. hordei) confers enhanced susceptibility of barley to the necrotrophic fungus Bipolaris sorokiniana (teleomorph: Cochliobolus sativus). Acta. Biol. Szeged. 46:135-136.

Kobayashi, Y., Yamada, M., Kobayashi, I., and Kunoh, H. 1997. Actin microfilaments are required for the expression of nonhost resistance in higher plants. Plant Cell Physiol. 38:725-733.

Kumar, J., Huckelhoven, R., Beckhove, U., Nagarajan, S., and Kogel, K. H. 2001. A compromised Mlo pathway affects the response of barley to the necrotrophic fungus Bipolaris sorokiniana (teleomorph: Cochliobolus sativus) and its toxins. Phytopathology 91:127-133.

Kwon, C., Bednarek, P., and Schulze-Lefert, P. 2008. Secretory pathways in plant immune responses. Plant Physiol. 147:1575-1583.

Li, X., Lin, H., Zhang, W., Zou, Y., Zhang, J., Tang, X., and Zhou, J. M. 2005. Flagellin induces innate immunity in nonhost interactions that is suppressed by Pseudomonas syringae effectors. Proc. Natl. Acad. Sci. USA 102: 12990-12995.

Li, W., Xu, Y. P., Zhang, Z. X., Cao, W. Y., Li, F., Zhou, X., Chen, G. Y., and Cai, X. Z. 2012. Identification of genes required for nonhost resistance to Xanthomonas oryzae pv. oryzae reveals novel signaling components. PLoS ONE 7:e42796.

Lipka, U., Fuchs, R., and Lipka, V. 2008. Arabidopsis non-host resistance to powdery mildews. Curr. Opin. Plant Biol. 11:404-411.

Lipka, V., Dittgen, J., Bednarek, P., Bhat, R., Wiermer, M., Stein, M., Landtag, J., Brandt, W., Rosahl, S., Scheel, D., Llorente, F., Molina, A., Parker, J., Somerville, S., and Schulze-Lefert, P. 2005. Pre- and postinvasion defenses both contribute to nonhost resistance in Arabidopsis. Science 310: 1180-1183.

Loehrer, M., Langenbach, C., Goellner, K., Conrath, U., and Schaffrath, U. 2008. Characterization of nonhost resistance of Arabidopsis to the Asian soybean rust. Mol. Plant-Microbe Interact. 21:1421-1430.

Lu, M., Tang, X., and Zhou, J. M. 2001. Arabidopsis NHO1 is required for general resistance against Pseudomonas bacteria. Plant Cell 13:437-447.

McGrann, G. R. D., Stavrinides, A., Russell, J., Corbitt, M. M., Booth, A., Chartrain, L., Thomas, W. T. B., and Brown, J. K. M. 2014. A trade off between mlo resistance to powdery mildew and increased susceptibility of barley to a newly important disease, Ramularia leaf spot. J. Exp. Bot. 65:1025-1037.

Mishina, T. E., and Zeier, J. 2007. Bacterial non-host resistance: Interactions of Arabidopsis with non-adapted Pseudomonas syringae strains. Physiol. Plant. 131:448-461.
Moreau, M., Degrave, A., Vedel, R., Bitton, F., Patrit, O., Renou, J. P., Barny, M. A., and Fagard, M. 2012. EDS1 contributes to nonhost resistance of Arabidopsis thaliana against Erwinia amylovora. Mol. Plant-Microbe Interact. 25:421-430.

Moscou, M. J., Lauter, N., Steffenson, B., and Wise, R. P. 2011. Quantitative and qualitative stem rust resistance factors in barley are associated with transcriptional suppression of defense regulons. PLoS Genet. 7:e1002208.

Mysore, K. S., and Ryu, C. M. 2004. Nonhost resistance: How much do we know? Trends Plant Sci. 9:97-104.

Nakao, M., Nakamura, R., Kita, K., Inukai, R., and Ishikawa, A. 2011. Nonhost resistance to penetration and hyphal growth of Magnaporthe oryzae in Arabidopsis. Sci. Rep. 1:171.

Niks, R. E., and Marcel, T. C. 2009. Nonhost and basal resistance: How to explain specificity? New Phytol. 182:817-828.

Nimchuk, Z., Eulgem, T., Holt, B. F., 3rd, and Dangl, J. L. 2003. Recognition and response in the plant immune system. Annu. Rev. Genet. 37: 579-609.

Nyadanu, D., Akromah, R., Adomako, B., Kwoseh, C., Dzahini-Obiatey, H., Lowor, S. T., Akrofi, A. Y., and Assuah, M. K. 2012. Host plant resistance to Phytophthora pod rot in cacao (Theobroma cacao L.): The role of epicuticular wax on pod and leaf surfaces. Int. J. Bot. 8:13-21.

Parker, J. E., Holub, E. B., Frost, L. N., Falk, A., Gunn, N. D., and Daniels, M. J. 1996. Characterization of eds1, a mutation in Arabidopsis suppressing resistance to Peronospora parasitica specified by several different RPP genes. Plant Cell 8:2033-2046

Peart, J. R., Lu, R., Sadanandom, A., Malcuit, I., Moffett, P., Brice, D. C., Schauser, L., Jaggard, D. A. W., Xiao, S., Coleman, M. J., Dow, M., Jones, J. D. G., Shirasu, K., and Baulcombe, D. C. 2002. Ubiquitin ligaseassociated protein SGT1 is required for host and nonhost disease resistance in plants. Proc. Natl. Acad. Sci. USA 99:10865-10869.

Pennisi, E. 2010. Armed and dangerous. Science 327:804-805.

Pretorius, Z. A., Singh, R. P., Wagoire, W. W., and Payne, T. S. 2001. Detection of virulence to wheat stem rust resistance gene Sr31 in Puccinia graminis f. sp. tritici in Uganda. Plant Dis. 84:203.

Raffaele, S., Farrer, R. A., Cano, L. M., Studholme, D. J., MacLean, D., Thines, M., Jiang, R. H., Zody, M. C., Kunjeti, S. G., Donofrio, N. M., Meyers, B. C., Nusbaum, C., and Kamoun, S. 2010. Genome evolution following host jumps in the Irish potato famine pathogen lineage. Science 330:1540-1543

Riley, R., and Macer, R. C. F. 1966. The chromosomal distribution of the genetic resistance of rye to wheat pathogens. Can. J. Genet. Cytol. 8: 640-653.

Roelfs, A. P. 1978. Estimated losses caused by rust in small grain cereals in the United States, 1918-76. U.S. Department of Agriculture, Agricultural Research Service, U.S. Govt. Print. Off., Washington.

Roelfs, A. P. 1982. Effects of barberry eradication on stem rust in the United States. Plant Dis. 66:177-181.

Rojas, C. M., Senthil-Kumar, M., Wang, K., Ryu, C. M., Kaundal, A., and Mysore, K. S. 2012. Glycolate oxidase modulates reactive oxygen speciesmediated signal transduction during nonhost resistance in Nicotiana benthamiana and Arabidopsis. Plant Cell 24:336-352.

Rosewich, U. L., and Kistler, H. C. 2000. Role of horizontal gene transfer in the evolution of fungi. Annu. Rev. Phytopathol. 38:325-363.

Schulze-Lefert, P., and Panstruga, R. 2011. A molecular evolutionary concept connecting nonhost resistance, pathogen host range, and pathogen speciation. Trends Plant Sci. 16:117-125.

Senthil-Kumar, M., and Mysore, K. S. 2012. Ornithine-delta-aminotransferase and proline dehydrogenase genes play a role in non-host disease resistance by regulating pyrroline-5-carboxylate metabolism-induced hypersensitive response. Plant Cell Environ. 35:1329-1343.

Senthil-Kumar, M., and Mysore, K. S. 2013. Nonhost resistance against bacterial pathogens: Retrospectives and prospects. Annu. Rev. Phytopathol. 51: 407-427.

Shan, W., Cao, M., Leung, D., and Tyler, B. M. 2004. The Avrlb locus of Phytophthora sojae encodes an elicitor and a regulator required for avirulence on soybean plants carrying resistance gene Rps $1 b$. Mol. PlantMicrobe Interact. 17:394-403.

Shibata, Y., Kawakita, K., and Takemoto, D. 2011. SGT1 and HSP90 are essential for age-related resistance of Nicotiana benthamiana against the oomycete pathogen Phytophathora infestans. Physiol. Mol. Plant Pathol. 75:120-128.

Singh, R. P., Hodson, D. P., Huerta-Espino, J., Jin, Y., Bhavani, S., Njau, P., Herrera-Foessel, S., Singh, P. K., Singh, S., and Govindan, V. 2011. The emergence of $\mathrm{Ug} 99$ races of the stem rust fungus is a threat to world wheat production. Annu. Rev. Phytopathol. 49:465-481.

Stam, R., Mantelin, S., McLellan, H., and Thilliez, G. 2014. The role of effectors in nonhost resistance to filamentous plant pathogens. Front. Plant Sci. 5:582 
Stein, M., Dittgen, J., Sanchez-Rodriguez, C., Hou, B. H., Molina, A., Schulze-Lefert, P., Lipka, V., and Somerville, S. 2006. Arabidopsis PEN3/ PDR8, an ATP binding cassette transporter, contributes to nonhost resistance to inappropriate pathogens that enter by direct penetration. Plant Cell 18:731-746.

Sumit, R. 2013. Investigation of the Arabidopsis nonhost resistance mechanism against the soybean pathogen, Phytophthora sojae. Graduate Thesis and Dissertations, Iowa State University.

Sumit, R., Sahu, B. B., Xu, M., Sandhu, D., and Bhattacharyya, M. K. 2012. Arabidopsis nonhost resistance gene PSS1 confers immunity against an oomycete and a fungal pathogen but not a bacterial pathogen that cause diseases in soybean. BMC Plant Biol. 12:87.

Tadege, M., Wen, J., He, J., Tu, H., Kwak, Y., Eschstruth, A., Endre, G., Zhao, P. X., Chabaud, M., Ratet, P., and Mysore, K. S. 2008. Large scale insertional mutagenesis using the Tnt1 retrotransposon in the model legume Medicago truncatula. Plant J. 54:335-347.

Takemoto, D., Jones, D. A., and Hardham, A. R. 2003. GFP-tagging of cell components reveals the dynamics of subcellular re-organization in response to infection of Arabidopsis by oomycete pathogens. Plant J. 33:775-792.

Thordal-Christensen, H. 2003. Fresh insights into processes of nonhost resistance. Curr. Opin. Plant Biol. 6:351-357.

Tsuba, M., Katagiri, C., Takeuchi, Y., Takada, Y., and Yamaoka, N. 2002. Chemical factors of the leaf surface involved in the morphogenesis of Blumeria graminis. Physiol. Mol. Plant Pathol. 60:51-57.

Uppalapati, S. R., Ishiga, Y., Doraiswamy, V., Bedair, M., Mittal, S., Chen, J. H., Nakashima, J., Tang, Y. H., Tadege, M., Ratet, P., Chen, R. J., Schultheiss, H., and Mysore, K. S. 2012. Loss of abaxial leaf epicuticular wax in Medicago truncatula irg1/palm1 mutants results in reduced spore differentiation of anthracnose and nonhost rust pathogens. Plant Cell 24: 353-370.

van Baarlen, P., van Belkum, A., Summerbell, R. C., Crous, P. W., and Thomma, B. P. 2007. Molecular mechanisms of pathogenicity: How do pathogenic microorganisms develop cross-kingdom host jumps? FEMS Microbiol. Rev. 31:239-277.

van der Biezen, E. A., and Jones, J. D. G. 1998. The NB-ARC domain: A novel signaling motif shared by plant resistance gene products and regulators of cell death in animals. Curr. Biol. 8:R226-R228.

van der Hoorn, R. A., and Kamoun, S. 2008. From guard to decoy: A new model for perception of plant pathogen effectors. Plant Cell 20:2009-2017.

van Wees, S. C., and Glazebrook, J. 2003. Loss of non-host resistance of Arabidopsis NahG to Pseudomonas syringae pv. phaseolicola is due to degradation products of salicylic acid. Plant J. 33:733-742.
Vega-Arreguin, J. C., Jalloh, A., Bos, J. I., and Moffett, P. 2014. Recognition of an Avr3a homologue plays a major role in mediating nonhost resistance to Phytophthora capsici in Nicotiana species. Mol. Plant-Microbe Interact. 27:770-780.

Vera Cruz, C. M., Bai, J., Oña, I., Leung, H., Nelson, R. J., Mew, T. W., and Leach, J. E. 2000. Predicting durability of a disease resistance gene based on an assessment of the fitness loss and epidemiological consequences of avirulence gene mutation. Proc. Natl. Acad. Sci. USA 97: 13500-13505.

Vleeshouwers, V. G., van Dooijeweert, W., Govers, F., Kamoun, S., and Colon, L. T. 2000. The hypersensitive response is associated with host and nonhost resistance to Phytophthora infestans. Planta 210:853-864.

Wang, K., Senthil-Kumar, M., Ryu, C. M., Kang, L., and Mysore, K. S. 2012. Phytosterols play a key role in plant innate immunity against bacterial pathogens by regulating nutrient efflux into the apoplast. Plant Physiol. 158: 1789-1802.

Wang, K., Uppalapati, S. R., Zhu, X., Dinesh-Kumar, S. P., and Mysore, K. S. 2010. SGT1 positively regulates the process of plant cell death during both compatible and incompatible plant-pathogen interactions. Mol. Plant Pathol. 11:597-611.

Wang, X., Richards, J., Gross, T., Druka, A., Kleinhofs, A., Steffenson, B., Acevedo, M., and Brueggeman, R. 2013. The rpg4-mediated resistance to wheat stem rust (Puccinia graminis) in barley (Hordeum vulgare) requires Rpg5, a second NBS-LRR gene, and an actin depolymerization factor. Mol. Plant-Microbe Interact. 26:407-418.

Watson, I. A. 1981. Wheat and its rust parasites in Australia. Pages 129-147 in: Wheat Science-Today and Tomorrow. L. T. Evans and W. J. Peacock, eds. Cambridge University Press, Cambridge.

Wiermer, M., Feys, B. J., and Parker, J. E. 2005. Plant immunity: The EDS1 regulatory node. Curr. Opin. Plant Biol. 8:383-389.

Wulff, B. B. H., Horvath, D. M., and Ward, E. R. 2011. Improving immunity in crops: New tactics in an old game. Curr. Opin. Plant Biol. 14:468-476.

Zhao, B., Ardales, E. Y., Raymundo, A., Bai, J., Trick, H. N., Leach, J. E., and Hulbert, S. H. 2004. The avrRxol gene from the rice pathogen Xanthomonas oryzae pv. oryzicola confers a nonhost defense reaction on maize with resistance gene Rxo1. Mol. Plant-Microbe Interact. 17: 771-779

Zhao, B., Lin, X., Poland, J., Trick, H., Leach, J., and Hulbert, S. 2005. A maize resistance gene functions against bacterial streak disease in rice. Proc. Natl. Acad. Sci. USA 102:15383-15388.

Zipfel, C. 2008. Pattern-recognition receptors in plant innate immunity. Curr. Opin. Immunol. 20:10-16. 